\title{
EFFECT OF DIETARY ZEOLITE ON AMMONIA TOXICITY AND ON SOME OF BLOOD PARAMETERS IN COMMON CARP CYPRINUS \\ CARPIO
}

\author{
Alaa A. Abdulathem \\ Researcher \\ Abdulmotalib J. Al-Rudainy \\ Prof.
}

Dept. Pathol. and Poultry Dis.;Coll. Vet. Med.; University of Baghdad alrudainy612003@yahoo.com

\section{ABSTRACT}

The present study aimed to evaluate the effect of dietary zeolite on ammonia toxicity and in some of blood parameters in Cyprinus carpio. Fish were fed either a control diets ( $0 \%$ zeolite) or control diet supplemented with 2,4 and $6 \%$ (T1, T2 and T3) respectively for 28 days. Results showed that the mean value of ammonia concentrations ranged between $0.10 \mathrm{mg} / \mathrm{l}$ in $\mathrm{T} 1$ and $\mathrm{T3}$ in the first week to $1.85 \mathrm{mg} / \mathrm{l}$ in control in fourth week, which could be noticed a gradually increased in the values of ammonia in the end of the experiment. Results showed that the ammonia concentration has a significant $(p \leq 0.05)$ increased in control treatment for third and fourth week compared with other treatments. For blood parameters, results showed high fluctuation in the mean values of RBC count, the mean of WBC count recorded the highest value in control treatment, and significantly decreased in $T 1, T 2$ and $T 3$. PCV value and $\mathrm{Hb}$ content recorded the lowest values in control treatment and the highest values in $\mathrm{T} 1, \mathrm{~T} 2$ and $\mathrm{T} 3$ respectively. It can be concluded that $\mathrm{T} 3$ have reached the saturation point for lower values in the first three weeks of ammonia, then the active of zeolite decreased resulted increasing ammonia in fourth week for all treatments.

Key words: common carp, clinoptilolite, hematology,minerals, mortalities

عبدالعظيم والرديني

1283-1276:52:52:2021 مجلة العلوم الزراعية العراقية

تاثير الزيولايت في العليقة على سمية الامونيا ويعض المعايير الدمية في اسماك الكارب الثائع Cyprinus carpio

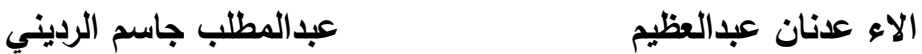

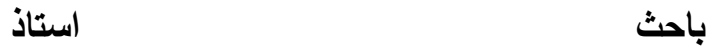

$$
\begin{aligned}
& \text { قسم الامراض وامراض الدواجن ،كلية الطب البيطري ، جامعة بغداد }
\end{aligned}
$$

المستخلص

هافت الدراسة الحالية لتقييم تاثير الغذاء الحاوي على الزيولايت على سمية الامونيا ويعض المعايير الدمية في سمكة الكارب الثائع Cyprinus carpio. تم تغذية الأسماك بعليقة السيطرة (0 ٪ زيوليت) أو عليقة السيطرة مضاف اليها 2 و و

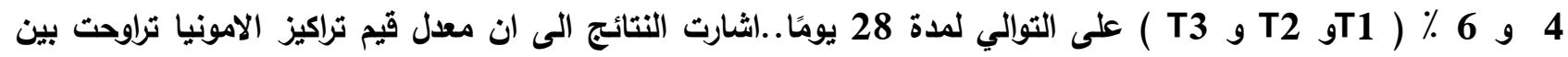
0,10ملفم/لتر في المعاملتين الاولى والثالثة في الاسبوع الاول الى 1,85 ملفم/لتر في معاملة السيطرة في الاسبوع الرابع، اذ اذ

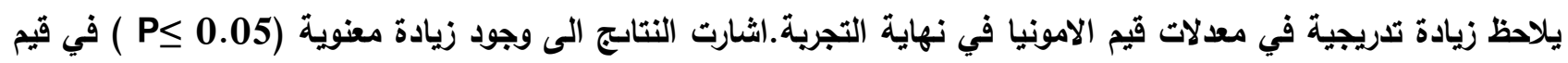

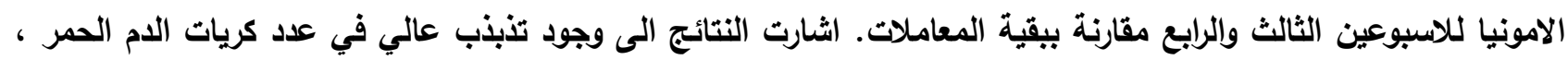
بينما سجلت كريات الدم البيض اعلى عدد لها في معاملة السيطرة ، بعدها انخفضت في المعاملة الاولى والثانية والثالثة. اشارت نتائج الدراسة الحالية بان قيم حجم خلايا الام المرصوصة والهيموغلوبين سجلت ادنى القيم في معاملة السيطرة واعلاها في المعاملات الاولى والثانية والثالثة. يمكن ان نستتنج بان المعاملة الثالثة وصلت الى نقطة التثبع للامونيا الى ادنى قيمة لها في الاسابيع الثلاثة الاولى الثى الكلمات المفتاحية: كارب شائع، كلينويتيلولايت، دم، معادن، هلاكات 


\section{INTRODUCTION}

Ammonia is toxic to aqueous life and reduces oxygen carriage capacity of hemoglobin. Furthermore, ammonia damages the gills and prevents fish to get oxygen $(17,29)$. The nature and degree of ammonia toxicity depends on many factors, including the chemical form of ammonia, $\mathrm{pH}$ and water temperature, period of exposure, and the life stage of the exposed fish (30). Ammonia is toxic to fish and other aquatic organisms in very low concentration about $0.2 \mathrm{mg} / \mathrm{l}(1,21)$. In rainbow trout Oncorhynchus mykiss, sublethal concentrations of ammonia can cause hyperexcitability, resulting in fish crashing into the sides of the tank in response to any disturbance (21). Zeolites are porous, hydrated aluminosilicates, may be natural minerals or synthetic materials. The general chemical composition of a zeolite is: $\mathrm{Mn} \mathrm{x} / \mathrm{nSi} 1-\mathrm{xAlxO} 2$ - yH2O. Pellet zeolite can easily be spread to the ponds by the farmers without dust. Pellet stays rigid until it falls to the bottom of the pond, turns into powder form and expands its surface area. Powder zeolite absorbs the toxins and ammonia and heavy metals with a greater efficiency $(12,23)$. The present study aimed to calculate the period in which zeolite affects ammonia and determine the best treatment of zeolite cause reduction of ammonia, as well as the effect of zeolite on hematological parameters (RBCs and WBCs count, $\mathrm{Hb}$ content and PCV value).

\section{MATERIALS AND METHODS \\ Preparation of diets and zeolite}

Four weeks of feeding trail were started using a commercial diet, with protein content of $28 \%$ total protein, the raw materials were grinded by using food grinder and weighed. Zeolite was grinded through a feed grinder to a very small particles to form powder, then added to the raw materials of pellets and mixed by hand until ingredients homogeneity. Each formulated diet was mixed to prepare each of the experimental diet. Warm water was added with continuous mixing. The paste like passed through meat mincer to produce pellets $(2 \mathrm{~mm}$ in diameter), then dried in room temperature. The diets collected and stocked in plastic containers and stored in refrigerator at $4{ }^{\circ} \mathrm{C}$ during the experimental periods to avoid the deterioration of nutrients. The experimental diets are:

Cont.: Use the commercial basal diet ( $0 \%$ zeolite).

T1 : Commercial basal diet with $2 \%$ zeolite .

$\mathrm{T} 2$ : Commercial basal diet with $4 \%$ zeolite.

T3 : Commercial basal diet with $6 \%$ zeolite

Each of the five treatment fish fed twice daily at rate of $3 \%$ body weight during the $f$ experimental trail .

\section{Experimental design}

The present study was conducted at the College of Veterinary Medicine, University of Baghdad, Fish Diseases Laboratory. A total of 200 fingerlings of common carp Cyprinus carpio with an average weight of $20 \mathrm{~g}$. were obtained from a commercial farm (AlMessayyab, Babylon). Fish were briefly bathed in $\mathrm{NaCl}$ for 5 minutes to remove all of the external parasites if present. Two weeks of acclimation for fish before starting the experiment. During this time, they were stocked in two baths with a dimensions of 150 $\times 80 \times 50 \mathrm{~cm}$. Then healthy fish were randomly selected and distributed into 10 glass aquariums (dimensions; 60x40x40 cm) at rate of 6 fish per aquaria (two replicates / treatment) were maintained for each of the five treatments (T1, T2, T3 and control) in dechlorinated water tap water filled the aquarium to reach 60L.Chemo-physical parameters of water such as temperature was recorded daily using thermometer, while $\mathrm{pH}$, dissolved oxygen (DO) were measured twice weekly, using $\mathrm{pH}$ meter and digital DO respectively. Aquariums are ventilated with air pumps and heater device to maintain the ventilation and temperature.

\section{Determination of Ammonia concentration}

Total ammonia was measured using drops

Kit: Hanna Ammonia test kit for fresh water : determines the ammonia concentration in water in several easy steps. The kit is portable and can be used in the field as well as in the laboratory.

Chemical reaction of kit : The ammonia level in $\mathrm{mg} / \mathrm{l}$, ammonia as nitrogen is determined by a colorimetric method. The nesssler reagent reacts with ammonia, under strong alkaline conditions, to form a yellow colored complex . an addition of reagent 1(EDTA solution) inhibits precipitation of calcium and 
magnesium ions due to the presence of the alkaline nessler reagent.. The color intensity of the solution determines the ammonia concentration

method of the kit: 1 . Remove the cap from the plastic beaker . rinse the plastic beaker with water sample before filling it up to the $10 \mathrm{ml}$ mark. Add 2 drops of ammonia reagent 1 for freshwater, replace the cap and mix by carefully swirling the beaker in tight circles. Add 8 drops of nessler reagent, replace the cap and mix by carefully swirling the beaker. Then remove the cap and transfer the solution into the color comparator cube, wait for 5 minutes to allow color to develop. Finally determine which color matches the solution in the cube, and record the results in $\mathrm{mg} / \mathrm{l} \mathrm{NH} 3-\mathrm{N}$. 6. it is better to match the color with a white sheet at about $10 \mathrm{~cm}$ behind the comparator.

\section{Hematological parameters}

Blood samples were collected from four fish randomly selected from tank. Samples were taken from caudal vein puncture using $3 \mathrm{ml}$ plastic syringe. Blood was transferred to eppendorf coated with lithium heparin that work as anticoagulant and used for measuring the hematological parameters. Dices fluid was used to dilute blood to count RBCs and WBCs by haemocytometer chamber. Pipette was filled it to the marker $(0.5)$ and diluted with the Dacies fluid was filled to mark (9) to make the dilution range 1:20, mixing well and remain for $5 \mathrm{~min}$. The counting chamber was filled and left for about 5 minutes, then the WBCs were counted in the four corner primary squares of the chamber and the RBCs are counted in five secondary squares of the center primary square. The following formulae were applied to calculate the WBCs, and RBCs (10):

Total WBCs count $=\frac{N \times 20}{0.1} \quad$ cell $/ \mu 1$

$\mathrm{N}$ : number of the cells in 1 large square ,20: dilution factor, 0.1 : volume factor $=$ (width $\mathrm{x}$ length $\mathrm{x}$ height).

Total RBCs count $=\frac{N \times 20 \times 5}{0.1}$ cell $/ \mu \mathrm{l}, 20$ : dilution factor, 0.1 : volume factor $=($ width $\mathrm{x}$ length $\mathrm{x}$ height).5: 5 squares equals

Concentration of $\mathrm{Hb}$ was determined by using the standard cyanomethemoglobin method described by Dacie and Lewis (9). Value of
PCV was determined according to the method described by Klontz (18).

\section{Statistical analysis}

The Statistical Analysis System- SAS (28) program was used to detect the effect of difference factors (Treatments and Period) in study parameters. Least significant difference -LSD test (Analysis of Variation-ANOVA) was used to significant compare between means in this study.

\section{RESULTS AND DISCUSSION Water quality}

Water temperature ranged between $17.4-$ $19.0{ }^{\circ} \mathrm{C}$ for all experimental treatments, $\mathrm{pH}$ values ranged between $7.7-8.2$, while dissolved oxygen level ranged between $5.4-$ $7.5 \mathrm{mg} / \mathrm{l}$. Finally salinity in water ranged from 0.05 to $0.08 \mathrm{~g} / \mathrm{l}$. These values within the limiting of live for warm fish particularly common carp $(22,27)$.

\section{Ammonia concentration and mortality rate}

Table 1 showed that the means of ammonia concentrations ranged between $0.10 \mathrm{mg} / \mathrm{l}$ in $\mathrm{T} 1$ and $\mathrm{T} 3$ to $1.85 \mathrm{mg} / \mathrm{l}$ in control, which could be noticed a gradually increased in the values of ammonia from $0.18 \mathrm{mg} / \mathrm{l}$ in first week to the highest value in the fourth week attained $1.85 \mathrm{mg} / \mathrm{l}$ in control treatment. Mortality rate was increased reached to $100 \%$ in the fourth week (Tab.2).Mean values of ammonia have continuously increased in $\mathrm{T} 1$, which ranged between $0.10-1.00 \mathrm{mg} / \mathrm{l}$ in first and fourth week respectively with increasing of mortality rate reached up to $66.66 \%$ in fourth week (Tab.2), also observed in T2 and T3 which ranged between $0.14 \mathrm{mg} / \mathrm{l}$ in first week to $0.98 \mathrm{mg} / \mathrm{l}$ in fourth week for T2; between 0.10 - $1.24 \mathrm{mg} / \mathrm{l}$ in first and fourth week respectively for $\mathrm{T} 3$, and between $0.18-0.70$ $\mathrm{mg} / \mathrm{l}$ in the same weeks for T4 . No significant different $(p>0.05)$ in T2 was observed within second and third weeks. On the contrary there are significant increased $(p \leq 0.05)$ within previous week in T1 and T3. In fourth week the value of ammonia continued increased significantly $(\mathrm{p} \leq 0.05)$ in all treatments, so it can be concluded that $\mathrm{T} 3$ have reached the saturation point for lower values in the first three weeks of ammonia, then the effect of zeolite decreased resulted increasing ammonia in fourth week for all treatments . Tab. 1 showed that the ammonia concentration has a 
significant increased $(\mathrm{p} \leq 0.05)$ in control treatment for third and fourth week compared with other treatments. Results of statistical analysis of ammonia concentration showed no significant difference $(\mathrm{p}>0.05)$ among experimental treatments in first week. Generally results showed that ammonia and mortality decreased with increased dietary zeolite. Mortality rate in the end of experiment reached $66.66 \%$ in $\mathrm{T} 1$ and $\mathrm{T} 2$, while it was $50.0 \%$ in $\mathrm{T} 3$, it can be noticed increased of mortality rate in the fourth week especially in control treatment which reached up to $100 \%$ (Tab.2).

Table 1. Mean $( \pm$ SD mg/l) values of ammonia in different treatments during experimental period

\begin{tabular}{|c|c|c|c|c|c|}
\hline \multirow[t]{2}{*}{ week } & \multicolumn{5}{|c|}{ Mean \pm SD of Ammonia $(\mathrm{mg} / \mathrm{l})$} \\
\hline & Cont. & T1 & $\mathbf{T 2}$ & T3 & LSD value \\
\hline $1^{\text {st }}$ & $0.18 \pm 0.07$ & $0.10 \pm 0.01$ & $0.14 \pm 0.03$ & $0.10 \pm 0.01$ & 0.119 NS \\
\hline & A c & A $\quad$ c & A $\quad$ c & A $\quad$ c & \\
\hline $2^{\text {nd }}$ & $0.59 \pm 0.08$ & $0.60 \pm 0.08$ & $\mathbf{0 . 5 0} \pm \mathbf{0 . 0 7}$ & $0.22 \pm 0.05$ & $0.207 *$ \\
\hline & & A b & AB $\quad \mathbf{b}$ & C c & \\
\hline $3^{\text {rd }}$ & $1.17 \pm 0.12$ & $0.70 \pm 0.09$ & $0.60 \pm 0.08$ & $0.44 \pm 0.07$ & $0.289 *$ \\
\hline & $\mathbf{A} \quad \mathbf{a}$ & B $\mathbf{a b}$ & B $\mathbf{b}$ & B b & \\
\hline $4^{\text {th }}$ & $1.85 \pm 0.14$ & $1.00 \pm 0.11$ & $0.98 \pm 0.09$ & $1.24 \pm 0.11$ & $0.865 *$ \\
\hline LSD value & $\underset{0.613}{\mathbf{A}} \mathbf{a}$ & $\underset{0.326}{\mathbf{A}} \mathbf{a}$ & 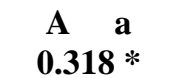 & $\begin{array}{c}\mathbf{A} \\
0.224\end{array}$ & --- \\
\hline
\end{tabular}

Means with different small letters in the same column and capital letters in the same row are significantly different. $(P \leq \mathbf{0 . 0 5})$.

Table 2. Mortality rate in different treatments during experimental period

\begin{tabular}{|c|c|c|c|c|c|}
\hline Treatment & \multicolumn{4}{|c|}{ No. of dead fish (week) } & Mortality rate \\
\hline & $\overline{1 s t}$ & $2^{\text {nd }}$ & 3rd & $4^{\text {th }}$ & $\%$ \\
\hline Cont. & $\mathbf{0}$ & 1 & 2 & 3 & 100.00 \\
\hline T1 & $\mathbf{0}$ & 1 & 1 & 2 & 66.66 \\
\hline T2 & $\mathbf{0}$ & 1 & 1 & 2 & 66.66 \\
\hline T3 & $\mathbf{0}$ & $\mathbf{0}$ & 1 & 2 & $\mathbf{5 0 . 0 0}$ \\
\hline
\end{tabular}

Different fish species have different sensitivity to different concentrations of the ammonia. For example, Salmonids (. Salmo salar) are more sensitive than the other fish species, due to their high oxygen need (2). Brinkmans (7) reported that chronic exposure in early life stages to ammonia concentrations as low of unionized ammonia nitrogen (UIAN) caused significant reductions in survival rate. Results of the present study are similar to Farhangi and Hajimoradloo (13) who indicated that this ability to absorb ammonia by the zeolite after some time depends on the amount of zeolite that used for removal ammonia compounds and with decreasing ammonia, the zeolites reached the saturation point and not being able to continue the absorbing of this compounds, the levels of ammonia from 0.01 to $1.0 \mathrm{mg} / 1$ reduced growth of freshwater fish. In general, $0.02 \mathrm{mg} / \mathrm{l}$ is considered as limit for ammonia in aquaculture (30).Furthermore, when the zeolite is saturated, it can be reused after treatment with salt water. Muir (22) reported that effects of ammonia $(0.130 \mathrm{mg} / \mathrm{l})$ on growth for Tilapia, by using zeolite, removing of ammonia molecules was faster with increasing of the zeolite concentrations in different treatments until zeolite reached the saturation point, hereby a particular amount of zeolite needed to be added as an active absorbance to remove the ammonia from the water solution. Ammonia excretion rates were investigated as a function of zeolite dosage in rainbow trout dietary, a diet with $2.5 \%$ natural zeolite decreased ammonia discharge by $24 \%$ compared to the control group of trout (12). Moreover, to improve water quality in aquaponic production of red tilapia Oreochromis sp. and lettuce Lactuca sativa . longifolia, natural zeolite has been reported to be very effective (26). Fish fed with zeolitesupplemented diets in different levels, ammonia and ammonium were found relatively to be lower than in control group $(1,12)$. Obradović et al. (24) revealed that the diet containing zeolite decreased the release of ammonia. An important attribute of the zeolite is its capacity to effectively bind ammonia and, as a result, to reduce ammonia concentration by release into the environment (27). Zeolite, as feed additive, can contribute removal of excess ammonia in the digestive 
system (4,27). However, it should be considered that some other factors, such as energy level or amino acid balance, as well as the growth rate, fish size or physiological state, feed intake and some various environmental and cultural conditions, might also affect the postprandial ammonia excretion in fish (19). Diet quality and feed ingredients are also important factors affecting ammonia excretion, (i.e. a better diet utilization may result in a lower ammonia excretion by fish). In contrary to present study, $\mathrm{Oz}$ et al.(25) stated that ammonia concentrations reached the highest level in the control group on 9th day of the study $(1.6 \mathrm{mg} / \mathrm{l})$, and on the same day it was $0.9 \mathrm{mg} / \mathrm{l}$ and $0.2 \mathrm{mg} / \mathrm{l}$ respectively in groups comprising natural zeolite, so it was found that the effect of natural zeolite had a positive effect on aquarium water conditions in terms of reducing the increasing ammonia concentrations levels. Öz et al. (25) detected that zeolite that was put inside a net bag reduced ammonia content in fish tanks $72 \%$, while zeolite that was put in aquarium directly reduced ammonia by $33 \%$ compared with control. However, use of zeolite in the aquaculture a net bag inside will have advantages such as higher ammonia adsorption levels, prevention of aquarium water turbidity, and easy removal from production area for conditioning process, therefore, use of zeolite inside a net bag can be recommended (25). As aquarium fish are in a limited capacity of water, so keeping water conditions within the ideal range is one of the most important activities to be performed. The most important factors affecting water conditions are metabolic waste of live animals and unconsumed feed (5). According to the report of Farhangi et al. (14), adding $10 \mathrm{~g} / \mathrm{l}$ zeolite was an optimum dose for improvement of water quality in angel fish culture, natural zeolite was applied for reduction of ammonia lethal concentration in rainbow trout culture (13). Zeolites has the ability to reduce the content of ammonia in both fresh and marine waters with efficiency exceeded $83 \%$ when the initial content of ammonia was $\leq 1.0 \mathrm{ppm}(3,6)$. Aly et al.(3) concluded that ammonia removal efficiency in freshwater is better than marine water. Zeolite has great potential for removing ammonia from water, especially at salinities lower than $10 \mathrm{~g} / \mathrm{l}$, but the main obstacle in using zeolite is its uselessness after a few hours (9). Farhangi and Hajimoradloo (11) reported that the use of $15 \mathrm{~g} / 1$ powder zeolite can prevent mortality rate of rainbow trout fish. However the complete removal of ammonia was not achieved even when zeolite was applied at $12 \mathrm{~g} / 1$ concentration.

\section{Hematological parameters}

Table 3. showed high fluctuations in the mean values of RBC, ranged between $1.99-2.55$ $\times 10^{6} / \mathrm{mm}^{3}$ in control and the T3 respectively, whereas the mean value of WBC recorded highest value in control treatment which reached $23.52 \times 10^{3} / \mathrm{mm}^{3}$, then decreased to $20.13 \times 10^{3} / \mathrm{mm}^{3}$ in $\mathrm{T} 1$ with gradual decline in T2 and T3 attained 20.25 and $20.16 \times 10^{6} / \mathrm{mm}^{3}$ respectively. Results of present study showed that the PCV values ranged between $24.0 \%$ in control treatment to $35.25 \%$ in $\mathrm{T} 3$, this result also recorded in $\mathrm{Hb}$ values which attained 6.90 in control treatment with gradually increase reached $11.70 \mathrm{~g} / \mathrm{dl}$ in $\mathrm{T} 3$ (Tab.3).Results of statistical analysis showed that RBC value with significant different $(\mathrm{p} \leq 0.05)$ in $\mathrm{T} 3$ compared with control and $\mathrm{T} 1$, but no significant different $(p>0.05)$ compared with $\mathrm{T} 2$. While the values of WBC showed significant different $(p \leq 0.05)$ in control treatment compared with other treatments. The values of $\mathrm{PCV}$ in $\mathrm{T} 3$ showed significant different $(p \leq 0.05)$ compared with other treatments, this corresponds completely to the $\mathrm{Hb}$ values. Results in Tab. (3) showed that the T3 can be considered as better treatment that contained zeolite $(6 \%)$ in all values of the studied blood parameters followed by T2 (4\% zeolite). 
Table 3. Hematological parameters (means \pm SD) of $C$. carpio at the end of experimental period

\begin{tabular}{|c|c|c|c|c|}
\hline Treatment & RBC cells $\times 10^{6} / \mathrm{mm}^{3}$ & $\begin{array}{c}\mathrm{WBC} \\
\text { cells } \times 10^{3} / \mathrm{mm}^{3}\end{array}$ & PCV (\%) & Hb g/dl \\
\hline Cont. & $1.99 \pm 0.25$ & $23.52 \pm 1.37$ & $\begin{array}{c}24.00 \pm 1.70 \\
b\end{array}$ & $\begin{array}{c}6.90 \pm 0.52 \\
c\end{array}$ \\
\hline T1 & $\begin{array}{c}b \\
2.05 \pm 0.13\end{array}$ & $\stackrel{a}{20.13} \pm 1.20$ & $\begin{array}{c}27.50 \pm 2.08 \\
b\end{array}$ & $\begin{array}{c}9.24 \pm 0.26 \\
b\end{array}$ \\
\hline $\mathbf{T} 2$ & $\begin{array}{c}\text { b } \\
2.22 \pm 0.22\end{array}$ & $\begin{array}{c}b \\
20.25 \pm 1.55\end{array}$ & $\begin{array}{c}28.75 \pm 2.63 \\
b\end{array}$ & $\begin{array}{c}9.60 \pm 0.96 \\
b\end{array}$ \\
\hline T3 & $\begin{array}{c}\mathrm{a} \\
2.55 \pm 0.18 \\
\mathrm{a}\end{array}$ & $\begin{array}{c}\text { b } \\
20.16 \pm 1.03 \\
b\end{array}$ & $\begin{array}{c}35.25 \pm 1.70 \\
\mathrm{a}\end{array}$ & $\begin{array}{c}11.7 \pm 0.36 \\
a\end{array}$ \\
\hline
\end{tabular}

Means with different small letters in the same column are significantly different $(\mathbf{p} \leq \mathbf{0 . 0 5})$

Ammonia toxicant is a serious problem and can cause big mortalities in fish as showed in present study. On the contrary, there were no dramatically increased concentrations of ammonia in the fish blood (31). Highest values of RBC in present study were recorded in T3 are agreement with Güler and Uçar (16) who observed that the highest erythrocyte sedimentation rate value was in $3 \%$ zeolite additive feed and the lowest in $1 \%$ zeolite additive feed in Oncorhynchus mykiss .The sudden increase in erythrocytes can be explained by the stress-induced induction of catecholamine by contraction of the spleen and new erythrocytes participating in circulation (16). Results of RBC count in present study showed higher in treatments than control, a reduction in RBC numbers below the normal range in fish is assumed to be an indicator of anemia (20), which acts as an indicator with subsequent result of inhibition of erythropoietin in the haemopoietic organisms. When the effect of zeolite on the leucocytes count was examined, the highest value was measured in fish fed with $5 \%$ zeolite feed, the lowest value was obtained in fish fed $3 \%$ zeolite, it means that WBC increased with increased zeolite (16), the previous results are agreement with the present study that observed the highest value in control treatment and the lower value recorded in $\mathrm{T} 1 \mathrm{using} 2 \%$ zeolite, as well as the highest value in control treatment and lowest value in T1 $(6 \mathrm{mg} / \mathrm{l}$ zeolite). WBC number generally increases after deteriorate of homeostasis due to an exposure to a stressful factor (8). $\mathrm{Hb}, \mathrm{WBC}$ and $\mathrm{RBC}$ values obtained from the present study are agreement with the study of gilthead sea bream(15).In present study a reduction of hemoglobin in control treatment may be due to inhibition of aerobic glycolysis, prolonged reduction in hemoglobin content is deleterious to transport any blood dyspepsia and degenerated and could be ascribe as pathological conditions in fish exposed to toxicants(8). It can be concluded that T3 have reached the saturation point for lower values in the first three weeks of ammonia, then the active of zeolite decreased resulted increasing ammonia in fourth week .

\section{REFFRENCES}

1. Abbas, H.H. 2006. Acute toxicity of ammonia to common carp fingerlings $(C$. carpio) at different pH levels. Pak. J. of Biol. Sci., 9(12):2215-2221

2. Abdullah, S. and J. Muhammad. 2006. Studies on acute toxicity of metals to the fish, Salmo salar. Pak. J. Biol.Sci., 9: 1807-1811

3. Aly, H.A., M.M. Abdel-Rahim, A.M. Lotfy, B.S. Abdelaty and R. Sallam. 2016. The applicability of activated carbon, natural zeolites, and probiotics (EM®) and its effects on ammonia removal effciency and fry performance of European Seabass Dicentrarchus labrax. J. Aquac. Res. Develo., 7(11):2-8

4. Boranic, M. 2000. What a physician should know about zeolites.Lijec. Vjesn., 122: 292298

5. Boyd, C. E. 1990. Water Quality in Ponds for Aquaculture, Auburn, Al: Auburn University, Alabama Agricultural Experiment Station, Press. 482P. (It was taken: Boyd, C. E., Practical Aspects of Chemistry in Pond Aquaculture, The Prog. Fish Cult., 59 : 85-93.

6. Boyd, C.E. 1995. Bottom Soils, Sediment, and Pond Aquaculture. Chapman and Hall, New York, $348 \mathrm{p}$

7. Brinkmans, S. 2009.Chronic toxicity of ammonia to early life stage Rainbow Trout.Trans. of the Am. Fish. Soc., 138:433440, 200. 
8. Çelik, E.Ş. 2006. Balıkların Kan Parametreleri Üzerine Ağır Metallerin Etkisi. E.Ü.

9. Dacie, J. V. and S. M. Lewis. 1995. Practical Haematology, 8th ed. Churchill Livingstone, Edinburgh; New York, 609P

10. Douglas, J., K. Weiss and W. Jane. 2010. Schalm's Veterinary Hematology, USA., 6th Edition, Blackwell Publishing Ltd, pp. 9941003

11. Emadi, H., J.E. Nezhad and H. Pourbagher. 2001. In vitro comparison of zeolite (clinoptilolite) and activated carbon as ammonia absorbent's in fish culture. Naga The ICLARM Quarterly, 24 (1-2): 1-3

12. Erg€un, S., H.Tekesoglu and M.Yigit. 2008. Effects of dietary natural zeolite levels on ammonia excretion rates in young rainbow trout Oncorhychus mykiss. Fresenius Environ. Bull., 17(2): 245-248

13. Farhangi, M. and A. M. Hajimoradloo. 2008. Effect of Clinoptilolite Zeolite to Prevent of Mortality in Rainbow Trout (Oncorhynchus mykiss) by Total Ammonia $\left(\mathrm{NH}_{4}-\mathrm{N}\right)$ Concentration. 1st Int. Congress on Aqua. Anim. Heal. Manag. Dis., January, 2728, Tehran-Iran

14. Farhangi, M., H. Gholipour-Kanani and F. Rostami-Charati. 2013. Prevention of acute ammonia toxicity in bluga (Huso huso),using natural zeolite. J. of Toxic. and Environ. Heal. Sci., 5: 73-78

15. Fazio, F., S. Marafioti, F. Arfuso, G. Piccione and C. Faggio. 2013. Comparative study of the biochemical and haematological parameters of four wild Tyrrhenian fish species. Vet. Med.,(11): 576-581

16. Güler, A. and A. Uçar. 2018. Effects of zeolite on growth and hematology of rainbow trout Oncorhynchus mykiss kept at low temperatures. Iran. J. Fish. Sci., DOI: 10.22092/ijfs.2018.117874

17. Kanyılmaz, M., N. Tekelioglu , H. Sevgili, R. Uysal and A. Aksoy. 2015. Effects of dietary zeolite (clinoptilolite) levels on growth performance, feed utilization and waste excretions by gilthead sea bream juveniles (Sparus aurata).Anim. Feed Sci.Techno.,6675

18. Klontz, G. W. 1997. Fish Haematology. In: Stolen, J. S.; T. C. Fletcher; A. F. Rowley; J. T. Zelikoff ; S. L. Kaattari and S. A. Smith
(Eds.), Techniques in Fish Immunology-3 (2nd), SOS Puplications,NJ, USA.,1sted, 258 $\mathrm{p}$

19. Leung, K.M.Y., J.C.W. Chu and R.S.S. Wu. 1999. Interacting effects of water temperature and dietary protein levels on postprandial ammonia excretion by the areolated grouper Epinephelus areolatus (Forskal). Aquac. Res., 30 : 793-798

20. Maita, M. 2007. Fish health assessment. Dietary Supplements for the Health and Quality of Cultured Fish, CAB International,10-34

21. McKenzie, D. J., A. Shingles , G. Claireaux and P. Domenic. 2008. Sublethal concentrations of ammonia impair performance of the teleost fast-start escape response. Physiol. and Bioch. Zool., University of Chicago, 82(4):353-362

22. Muir, J., J. Rijn and J. Hargreaves. 2000. Production in Intensive and Recycle Systems. In: Tilapias: Biology and Exploitation (ed. by Beveridge, M.C.M. and McAndrew, B.J.),pp. 405- 445.Kluwer Academic Publishing, Netherlands

23. Nieves, M., D. Voltolina, A. Medina, P. Piña and J.L. Ruiz.2002. Zeolites and diatom growth. Aquac. Res., 33: 75-79.

24. Obradović, S., M. Adamović, M. Vukasinović, R. Jovanović and J. Levic. 2006.The application effects of natural zeolite in feed and water on production results of Onchorhynchus mykiss (Walbaum). Roumanian Biotechnological Letters ,11: 3005-3013

25. Öz, M., D. Sahin and O. Oral. 2016. The effect of natural Zeolite Clinoptilolite on aquarium water conditions. Hacettepe Journal. Biolo. Chem., 44(2): 205-208

26. Rafiee, Gh, R. and R. Saad. 2005. Effects of dietary zeolite on growth of red tilalapia (Oreochromis Sp.) and lettuce (Lactuca sativa) in an aquaponic system. Iranian J. Nat. Res., 58: 363-371

27. Riche, M. and D. Garling. 2003. Feeding Tilapia in Intensive Recirculating Systems. NCRAC Fact Sheet Series 114, NCRAC Publications Office, Iowa State University, Ames,US

28. SAS. 2012. Statistical Analysis System, User's Guide. Statistical.Version 9.1 ${ }^{\text {th }}$ ed. SAS. Inst. Inc. Cary. N.C. USA 
29. Stickney, R.R. 1994 . Principles of Aquaculture. John Wiley and Sons.

30. Stuart, M. and M.S. Levit. 2010.A Literature Review of Effects of Ammonia on Fish. Center for Science in Public Participation, 1-8
31. Thangam, Y., M. Perumayee, S. Jayaprakash, S. Umavathi and S.K. Basheer. 2014.Toxicity of ammonia in hemoglobin content to freshwater fish Cyprinus carpio (Common carp). IOSR J. of Eng. (IOSRJEN) www.iosrjen.org .4 (12) : 45-48. 